\section{Cancer incidence in the Western Amazon: population-based estimates in Rio Branco, Acre State, Brazil, 2007-2009}

\author{
Incidência de câncer na Amazônia ocidental: \\ estimativa de base populacional em Rio \\ Branco, Acre, Brasil, 2007-2009
}

Juliano de Pádua Nakashima 1

Rosalina Jorge Koifman 2

Sergio Koifman 2

\author{
${ }^{1}$ Centro de Alta \\ Complexidade em Oncologia, \\ Universidade de Brasília, \\ Brasília, Brasil. \\ 2 Escola Nacional de Saúde \\ Pública Sergio Arouca, \\ Fundação Oswaldo Cruz, Rio \\ de Janeiro, Brasil. \\ Correspondence \\ J. P. Nakashima \\ Centro de Alta Complexidade \\ em Oncologia, Universidade \\ de Brasília. \\ SGAN 605, Av. L2 Norte, \\ Brasília, $D F$ \\ 70910-900, Brasil. \\ julianonakashima@gmail.com
}

\begin{abstract}
Cancer incidence rates vary widely in Brazil. The literature on the subject for the western Amazon region is scarce. This study aimed to determine cancer incidence in the population of Rio Branco, Acre State. A total of 718 new cases were recorded during the study period. Among men, the five leading cancer sites were prostate (ASR 75.1), stomach (ASR 23.0), lung (ASR 19.1), colon and rectum (ASR 9.5), and leukemia (ASR 6.9). Among women, they were breast (ASR 41.5), cervix (ASR 41.3), lung (ASR 11.8), colon and rectum (ASR 11.0), and stomach (ASR 7.7). These indicators reveal that Rio Branco has a cancer incidence pattern that overlaps with epidemiological cancer patterns observed in developed and developing regions. The results of the study point to the importance of implementing a populationbased cancer registry - currently nonexistent in Rio Branco - as a factor to promote analysis of incident cases of the disease and monitoring of its evolution.
\end{abstract}

Neoplasms; Incidence; Disease Registries

\section{Introduction}

Cancer constitutes a grave public health problem in Brazil and in the world 1,2. The problem has worsened in recent years, especially in developing countries, as a result of the aging of the population and the adoption of lifestyles associated with the problem, such as smoking, inactivity, diets high in animal fat and carbohydrates, and low intake of fiber, fruits, and vegetables 2 In this setting, it is crucial that resources and efforts be directed towards orienting strategies for prevention and control of the disease. The establishment of effective measures for cancer control requires quality information on the distribution of its incidence and mortality rates.

In Brazil, the incidence rates of cancer vary widely according to the geographical region investigated 3 . This variation may be due to different reasons, especially heterogeneous profiles of exposure to the disease's risk factors in populations from the country's different regions ${ }^{4}$.

The population-based statistics on cancer incidence currently available for the northern municipalities come from Belém (Pará State) and Manaus (Amazonas State) 5, and estimates are inexistent for the western Amazon region. The literature regarding cancer incidence in the state of Acre is scarce and the only existing information is based on estimates prepared by the National Cancer Institute (Instituto Nacional de Câncer - INCA) ${ }^{6}$. These estimates are obtained through 
approximations based on the observed incidence in other capitals in the North Region and applied to the population of this state.

Given the lack of a population-based cancer registry in Rio Branco (Acre State), this study aimed to determine the incidence of cancer in that municipality from an active search of locally available data.

\section{Methods}

\section{Source of incidence data}

Data regarding new cases with diagnosis of cancer (incident cases) in the period June 2007 to June 2009 were obtained through active search of the following health service records available in the Municipality of Rio Branco: records from all hospital system units, which includes two public and two private hospitals; all pathological anatomy laboratory records; and the database of the Cancer Hospital Registry at the Cancer Hospital of Acre.

There are four pathological anatomy and/or cytopathology diagnostic services in Rio Branco, of which three are private and one public, the Acre State Hospital Foundation.

For morphologic and topographic classification of tumors, we used ICD-O 7 and ICD-10 8, respectively. In the survey of incident cases of neoplasia in the Municipality of Rio Branco, we included all patients with histopathologic diagnosis of cancer in the study period, corresponding to lesions with behavior code 3 (malignant behavior tumors, primary site) and code 6 (malignant, metastatic location) in the CID-O Morphology code, as well as intracranial and intraspinal tumors.

The information collected for each patient were full name, medical record number and/or exam number, sex, birthdate, age at the time of diagnosis, residence municipality, primary site, and tumor morphology. This information was entered into a computer database with special attention to its detailed verification, confirming the anatomical location of the tumor and the date of biopsy or surgery. With these procedures it was sought to avoid duplicate entries in the sample due to a patient having completed multiple tests, including biopsies, surgical specimens, and reoperations.

\section{Study population}

The population estimate for the Municipality of Rio Branco on July 1, 2008, stratified by sex and age, was obtained by consulting the Brazilian
Unified National Health System Department of Information Technology (DATASUS), which uses as a source the Brazilian Institute of Geography and Statistics (IBGE. Population data. http:// www.datasus.gov.br, accessed on February 23, 2010). The population data provided by DATASUS were stratified according to the following age groups: under 15 years, 15-39 years, $40-49$ years, 50-59 years, $60-69$ years, and 70 or more years.

Incidence rates were calculated using as the denominator the estimated population in the Municipality of Rio Branco on July 1, 2008, multiplied by 2.083 (the value corresponding to the total period of data collection, 25 months, expressed in years), thereby allowing the determination of the total person-years analyzed.

\section{Data analysis}

The frequencies distribution by sex of new neoplasia cases in the selected locations was obtained relative to all new cases for each sex during the period analyzed. The crude rates of cancer incidence by sex and age were obtained using the ratio of the number of new cases of malignant neoplasias in the period June 2007 to June 2009 to the total number of person-years exposed to the risk of developing the disease in the time period in question, expressed per 100,000 individuals. Subsequently, we used the direct method to determine incidence rates by sex, standardized by age, using as the standard population the world population proposed by Segi in 1960 and modified by Doll et al. 9 .

Incidence rates by sex and age group were determined by the ratio between the number of cases in each stratum and the total person-years at risk in an age group and of a particular sex, expressed as rates per 100,000 inhabitants.

\section{Results}

During the period June 2007 to June 2009, there were 718 new cases of malignant neoplasias (excluding non-melanoma skin cancer) recorded in the Municipality of Rio Branco, of which 342 cases $(47.6 \%)$ were in males and 376 in sex females. The 15 most common anatomical locations accounted for $90 \%$ of the total number of cases in males and $95 \%$ in females.

The age standardized cancer incidence rates (all sites except non-melanoma skin cancer) in the study period, standardized for age, were: 163.6/100,000 for men (Table 1) and 145.0/100,000 for women (Table 2). The ratio of age standardized incidence rates by sex (male/ female) was 1.13 . 
Table 1

Cancer incidence rates for males (per 100,000), by primary location and age group. Rio Branco, Acre State, Brazil, June 2007 to June 2009.

\begin{tabular}{|c|c|c|c|c|c|c|c|c|c|c|c|c|c|c|}
\hline \multirow[t]{2}{*}{ CID-10 } & \multirow[t]{2}{*}{ Primary location } & \multicolumn{11}{|c|}{ Age group (years) } & \multirow{2}{*}{$\begin{array}{l}\text { Crude } \\
\text { rate }\end{array}$} & \multirow{2}{*}{$\begin{array}{c}\text { Adjustec } \\
\text { rate }\end{array}$} \\
\hline & & $0-4$ & $5-9$ & $10-14$ & $15-19$ & $20-24$ & $25-29$ & $30-39$ & $40-49$ & $50-59$ & $60-69$ & $>70$ & & \\
\hline & All locations & 0.7 & 0.3 & 0.6 & 0.6 & 0.3 & 0.8 & 2.9 & 13.0 & 22.0 & 55.9 & 66.5 & 112.8 & 163.6 \\
\hline $\mathrm{C} 00-14$ & Lip, oral cavity, pharynx & 0.0 & 0.0 & 0.0 & 0.0 & 0.0 & 0.0 & 0.0 & 1.2 & 2.3 & 1.4 & 1.6 & 5.3 & 6.5 \\
\hline C15 & Esophagus & 0.0 & 0.0 & 0.0 & 0.0 & 0.0 & 0.0 & 0.0 & 0.0 & 1.4 & 0.7 & 0.5 & 2.3 & 2.6 \\
\hline C16 & Stomach & 0.0 & 0.0 & 0.0 & 0.0 & 0.0 & 0.0 & 0.5 & 1.6 & 5.0 & 6.5 & 9.3 & 16.5 & 23.0 \\
\hline C18-20 & Colon and rectum & 0.0 & 0.0 & 0.3 & 0.0 & 0.0 & 0.0 & 0.5 & 1.2 & 1.8 & 3.6 & 2.1 & 7.3 & 9.5 \\
\hline C22 & Liver & 0.4 & 0.0 & 0.0 & 0.0 & 0.0 & 0.0 & 0.0 & 0.4 & 0.9 & 0.7 & 0.5 & 2.0 & 2.9 \\
\hline C23-24 & Biliary ducts & 0.0 & 0.0 & 0.0 & 0.0 & 0.0 & 0.0 & 0.0 & 0.4 & 0.0 & 0.7 & 0.0 & 0.7 & 1.2 \\
\hline $\mathrm{C} 25$ & Pancreas & 0.0 & 0.0 & 0.0 & 0.0 & 0.0 & 0.0 & 0.0 & 1.6 & 0.0 & 0.0 & 0.0 & 1.3 & 1.6 \\
\hline C31 & Sinuses & 0.0 & 0.0 & 0.0 & 0.0 & 0.0 & 0.0 & 0.0 & 0.0 & 0.5 & 0.0 & 0.0 & 0.3 & 0.5 \\
\hline C32 & Larynx & 0.0 & 0.0 & 0.0 & 0.0 & 0.0 & 0.0 & 0.0 & 0.8 & 0.0 & 0.7 & 0.5 & 1.6 & 2.0 \\
\hline C33-34 & Lung & 0.0 & 0.0 & 0.0 & 0.0 & 0.0 & 0.0 & 0.0 & 2.4 & 6.0 & 9.3 & 4.7 & 11.2 & 19.1 \\
\hline C38 & Mediastinum & 0.0 & 0.0 & 0.0 & 0.0 & 0.0 & 0.3 & 0.0 & 0.0 & 0.0 & 0.0 & 0.0 & 0.3 & 0.3 \\
\hline C43 & Melanoma & 0.0 & 0.0 & 0.0 & 0.0 & 0.0 & 0.0 & 0.0 & 0.0 & 0.0 & 0.7 & 0.5 & 1.0 & 1.2 \\
\hline C49 & Soft tissues & 0.0 & 0.0 & 0.0 & 0.0 & 0.0 & 0.0 & 0.0 & 0.0 & 0.5 & 0.0 & 0.0 & 0.3 & 0.5 \\
\hline C60 & Penis & 0.0 & 0.0 & 0.0 & 0.0 & 0.0 & 0.0 & 0.3 & 0.0 & 0.0 & 0.7 & 0.5 & 1.0 & 1.5 \\
\hline C61 & Prostate & 0.0 & 0.0 & 0.0 & 0.0 & 0.0 & 0.0 & 0.3 & 1.6 & 4.1 & 26.5 & 42.6 & 48.2 & 75.1 \\
\hline C62 & Testicle & 0.0 & 0.0 & 0.0 & 0.0 & 0.0 & 0.0 & 0.0 & 0.4 & 0.0 & 0.0 & 0.0 & 0.7 & 0.4 \\
\hline C64 & Kidney & 0.0 & 0.0 & 0.0 & 0.0 & 0.0 & 0.0 & 0.0 & 0.4 & 0.5 & 0.0 & 0.0 & 1.0 & 0.9 \\
\hline C67 & Bladder & 0.0 & 0.0 & 0.0 & 0.0 & 0.0 & 0.0 & 0.0 & 0.0 & 0.5 & 2.2 & 1.1 & 2.6 & 3.6 \\
\hline C69 & Eye & 0.0 & 0.0 & 0.0 & 0.0 & 0.0 & 0.0 & 0.0 & 0.4 & 0.0 & 0.0 & 1.1 & 1.0 & 1.4 \\
\hline C70-72 & Brain & 0.0 & 0.0 & 0.0 & 0.3 & 0.0 & 0.0 & 0.3 & 0.4 & 0.5 & 0.0 & 0.0 & 1.3 & 1.4 \\
\hline C73 & Thyroid & 0.0 & 0.0 & 0.0 & 0.0 & 0.3 & 0.0 & 0.3 & 0.0 & 0.0 & 0.0 & 0.5 & 1.0 & 1.1 \\
\hline C81-85 & Lymphomas & 0.0 & 0.0 & 0.0 & 0.0 & 0.0 & 0.0 & 0.0 & 0.0 & 0.5 & 0.7 & 0.0 & 0.7 & 1.2 \\
\hline C91-95 & Leukemia & 0.4 & 0.3 & 0.3 & 0.3 & 0.0 & 0.5 & 0.8 & 1.2 & 0.5 & 1.4 & 0.5 & 4.6 & 6.9 \\
\hline
\end{tabular}

CID-10: International Statistical Classification of Diseases and Problems Related to Health, 10th revision 8.

The top five cancer incidence rates observed among men, adjusted by age, were, in descending order: prostate $(75.1 / 100,000)$, stomach (23.0/100,000), lung $(19.1 / 100,000)$, colon and rectum $(9.5 / 100,000)$, and leukemia $(6.9 / 100,000)$ (Table 1, Figure 1). Among women, these malignant neoplasias were breast $(41.5 / 100,000)$, cervix $(41.3 / 100,000)$, lung $(11.8 / 100,000)$, colon and rectum $(11.0 / 100,000)$, and stomach $(7.7 / 100,000)$ (Table 2, Figure 1).

Leukemia was the most frequent malignant neoplasia encountered among males in the age groups $0-14$ years $(0.9 / 100,000)$ and $15-39$ years $(1.4 / 100,000)$. Lung cancer was the primary tumor site in the age group 40-49 years $(2.4 / 100,000)$, stomach cancer in the range 50-59 years $(5.0 / 100,000)$, and prostate cancer in older age groups (26.5/100,000 for those 60-69 years old and 42.6/100,000 for those 70 years or older) (Table 1).
In females, cervical cancer was the most frequent neoplasia in the age group 15-39 years $(9.2 / 100,000)$, followed by breast cancer $(3.2 / 100,000)$. From the age of 40 , this scenario is reversed, with breast cancer being the most frequent in all of the other age groups, followed by cervical cancer (Table 2).

\section{Discussion}

The magnitudes of the standardized incidence rates of cancer (all locations except non-melanoma skin cancer) observed in the Municipality of Rio Branco for both for males and females are about half those found in more developed regions of the world and similar to those described for other developing regions 2 . Compared with other Brazilian cities, the rates found in Rio Branco may be considered moderate 5 . 
Table 2

Cancer incidence rates for females (per 100,000), by primary location and age group. Rio Branco, Acre State, Brazil, June 2007 to June 2009.

\begin{tabular}{|c|c|c|c|c|c|c|c|c|c|c|c|c|c|c|}
\hline \multirow[t]{2}{*}{ CID-10 } & \multirow[t]{2}{*}{ Primary location } & \multicolumn{11}{|c|}{ Age group (years) } & \multirow{2}{*}{$\begin{array}{c}\text { Crude } \\
\text { rate }\end{array}$} & \multirow{2}{*}{$\begin{array}{c}\text { Adjusteo } \\
\text { rate }\end{array}$} \\
\hline & & $0-4$ & $5-9$ & $10-14$ & $15-19$ & $20-24$ & $25-29$ & $30-39$ & $40-49$ & $50-59$ & $60-69$ & $>70$ & & \\
\hline & All locations & 0.4 & 0.3 & 0.8 & 1.7 & 0.7 & 3.4 & 11.5 & 27.1 & 37.8 & 33.6 & 27.8 & 115.8 & 145.0 \\
\hline $\mathrm{COO}-14$ & Lip, oral cavity, pharynx & 0.0 & 0.0 & 0.0 & 0.0 & 0.0 & 0.0 & 0.0 & 0.0 & 0.0 & 0.6 & 0.9 & 1.5 & 1.6 \\
\hline C15 & Esophagus & 0.0 & 0.0 & 0.0 & 0.0 & 0.0 & 0.0 & 0.0 & 0.0 & 0.0 & 0.0 & 0.9 & 0.6 & 0.9 \\
\hline $\mathrm{C} 16$ & Stomach & 0.0 & 0.0 & 0.0 & 0.0 & 0.2 & 0.0 & 0.0 & 1.0 & 3.0 & 0.6 & 2.8 & 6.2 & 7.7 \\
\hline C18-20 & Colon and rectum & 0.0 & 0.0 & 0.3 & 0.3 & 0.0 & 0.0 & 0.0 & 2.1 & 2.1 & 2.5 & 3.8 & 8.0 & 11.0 \\
\hline $\mathrm{C} 21$ & Anal canal & 0.0 & 0.0 & 0.0 & 0.0 & 0.0 & 0.2 & 0.0 & 0.0 & 0.4 & 0.6 & 0.5 & 1.5 & 1.8 \\
\hline $\mathrm{C} 22$ & Liver & 0.0 & 0.0 & 0.0 & 0.0 & 0.0 & 0.0 & 0.2 & 0.7 & 0.4 & 0.0 & 0.0 & 1.2 & 1.4 \\
\hline $\mathrm{C} 24$ & Biliary ducts & 0.0 & 0.0 & 0.0 & 0.0 & 0.0 & 0.0 & 0.0 & 0.0 & 0.0 & 1.2 & 0.9 & 0.6 & 2.2 \\
\hline $\mathrm{C} 25$ & Pancreas & 0.0 & 0.0 & 0.0 & 0.0 & 0.0 & 0.0 & 0.0 & 0.0 & 0.4 & 0.6 & 0.9 & 1.2 & 2.0 \\
\hline C30 & Nasal cavity & 0.0 & 0.0 & 0.0 & 0.0 & 0.0 & 0.0 & 0.0 & 0.0 & 0.0 & 0.6 & 0.0 & 0.3 & 0.6 \\
\hline C32 & Larynx & 0.0 & 0.0 & 0.0 & 0.0 & 0.0 & 0.0 & 0.0 & 0.0 & 0.0 & 0.6 & 0.0 & 0.3 & 0.6 \\
\hline C33-34 & Lung & 0.0 & 0.0 & 0.0 & 0.0 & 0.0 & 0.0 & 0.0 & 1.7 & 2.6 & 5.6 & 1.9 & 7.4 & 11.8 \\
\hline C43 & Melanoma & 0.0 & 0.0 & 0.0 & 0.0 & 0.0 & 0.0 & 0.0 & 0.0 & 0.0 & 0.0 & 0.5 & 0.3 & 0.5 \\
\hline C49 & Soft tissues & 0.4 & 0.0 & 0.0 & 0.0 & 0.0 & 0.0 & 0.0 & 0.0 & 0.0 & 0.0 & 0.0 & 0.3 & 0.4 \\
\hline C50 & Breast & 0.0 & 0.0 & 0.0 & 0.0 & 0.0 & 0.2 & 2.8 & 6.3 & 13.7 & 11.8 & 6.6 & 30.2 & 41.5 \\
\hline C51 & Vulva & 0.0 & 0.0 & 0.0 & 0.0 & 0.0 & 0.0 & 0.2 & 0.0 & 0.0 & 0.0 & 0.0 & 0.3 & 0.2 \\
\hline C52 & Vagina & 0.0 & 0.0 & 0.0 & 0.0 & 0.0 & 0.0 & 0.0 & 0.0 & 0.4 & 0.0 & 0.0 & 0.3 & 0.4 \\
\hline C53 & Cervix & 0.0 & 0.0 & 0.0 & 0.0 & 0.0 & 1.9 & 6.8 & 12.2 & 9.4 & 6.2 & 4.7 & 36.3 & 41.3 \\
\hline C54 & Uterine body & 0.0 & 0.0 & 0.0 & 0.3 & 0.2 & 0.0 & 0.7 & 0.7 & 2.1 & 0.0 & 0.9 & 4.6 & 5.0 \\
\hline C56 & Ovary & 0.0 & 0.0 & 0.3 & 0.3 & 0.2 & 0.0 & 0.2 & 0.3 & 0.4 & 0.0 & 0.5 & 3.1 & 2.3 \\
\hline C64 & Kidney & 0.0 & 0.0 & 0.0 & 0.0 & 0.0 & 0.0 & 0.0 & 0.0 & 0.4 & 2.0 & 0.0 & 1.5 & 1.7 \\
\hline C67 & Bladder & 0.0 & 0.0 & 0.0 & 0.0 & 0.0 & 0.0 & 0.0 & 0.3 & 0.4 & 0.6 & 0.5 & 1.2 & 1.9 \\
\hline C69 & Eye & 0.0 & 0.0 & 0.0 & 0.6 & 0.0 & 0.0 & 0.0 & 0.0 & 0 & 0.6 & 0.0 & 0.9 & 1.2 \\
\hline C70-72 & Brain & 0.0 & 0.3 & 0.0 & 0.0 & 0.0 & 0.0 & 0.0 & 0.3 & 0.4 & 0.0 & 0.9 & 1.5 & 2.0 \\
\hline C73 & Thyroid & 0.0 & 0.0 & 0.0 & 0.0 & 0.0 & 0.0 & 0.4 & 1.0 & 0.4 & 0.0 & 0.0 & 3.1 & 1.9 \\
\hline C81-85 & Lymphomas & 0.0 & 0.0 & 0.0 & 0.0 & 0.0 & 0.0 & 0.0 & 0.0 & 0.4 & 0.0 & 0.0 & 0.3 & 0.4 \\
\hline C91-95 & Leukemia & 0.0 & 0.0 & 0.3 & 0.3 & 0.0 & 1.0 & 0.0 & 0.0 & 0.4 & 0.0 & 0.5 & 2.5 & 2.4 \\
\hline
\end{tabular}

CID-10: International Statistical Classification of Diseases and Problems Related to Health, 10th revision 8.

The specific patterns by type of cancer and age group, i.e., predominance of leukemia in childhood and tendency for increased incidence rates of solid tumors in older individuals, are similar to those observed in the literature 6 .

The profile of cancer incidence in Rio Branco results from a wide range of factors, among which stand out the aging of the population and the persistence of high exposure to risk factors. The magnitude of the prevalence of risk factors for cancer development that exist in Rio Branco, such as high prevalence of smoking, inadequate diet, physical inactivity, alcohol consumption, and HPV and hepatitis infection, among others, contribute to broader understanding of the epidemiological impact of this disease 10,11,12,13,14.

Prostate cancer was the most common malignant neoplasia in Rio Branco, with an age standardized incidence rate of $75.1 / 100,000$ which is slightly lower than the rates cited for the regions of the world with the highest incidence, such as Australia $(104.2 / 100,000)$ and Western Europe $(94.1 / 100,000){ }^{2}$. From the perspective of national comparisons, the observed incidence in Rio Branco is similar to that found in other capitals with high incidence rates, such as Cuiabá (Mato Grosso State; 78.7/100,000) and Curitiba (Paraná State; 64.7/100,000) 15, and far superior to those described for other capitals in the North, such as Manaus $(30.9 / 100,000)$ and Belém $(16.7 / 100,000) 15$. The high rates observed in Rio Branco may be attributed both to screening programs, which enable diagnosis of early and latent cases of disease and those that otherwise would have remained undiagnosed 16 , as well as to the existence of a real increase in 


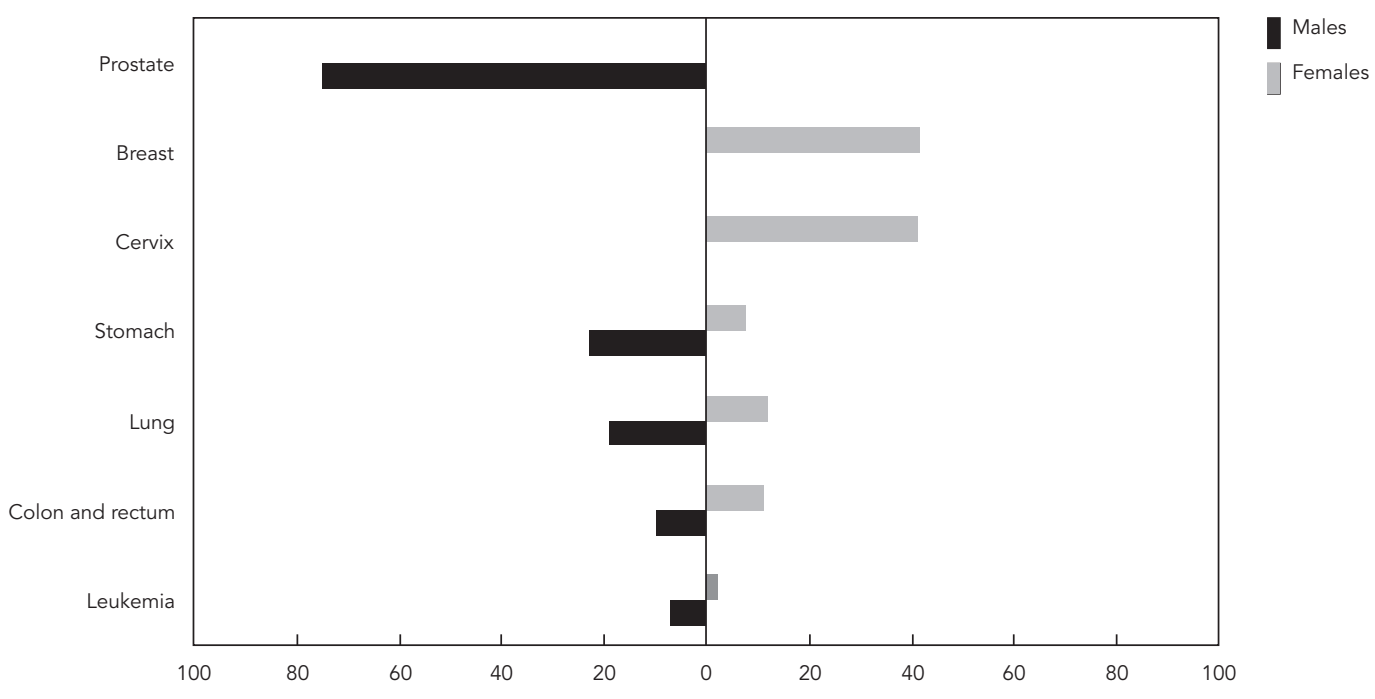

the risk of neoplasia due to the population aging process 17 and persistence of unhealthy lifestyle habits (sedentarism, excess weight, consumption of animal fat, among others).

Gastric cancer also presented a high incidence rate in males, with a magnitude roughly equivalent to half of those described for the regions of highest incidence worldwide, such as East Asia $(42.4 / 100,000) 2$, and similar to those described for the capitals in the North Region of Brazil (34.2/100,000 in Manaus and 27.6/100,000 in Belém) 15. Among women, gastric cancer was the fifth most common location. The epidemiological relevance of this neoplasia in Rio Branco could be partially explained by: the precarious living conditions (environmental sanitation and household crowding) that characterized local cohorts born in the last century, creating conditions conducive to Helicobacter pylori infection during the early stages of life; regional food habits, with high consumption of foods preserved in salt, and reduced intake of fruits and vegetables 10; and restricted access to refrigeration for preserving perishable foods 18 in past decades.

Lung cancer was the third most common neoplasia in both sexes. The incidence rate of lung cancer observed in males was much lower than those reported for high incidence regions, such as Eastern Europe $(57.0 / 100,000) 2$. National comparison shows that the incidence rate of lung cancer among men of Rio Branco is intermediate, being higher than those reported in Fortaleza $(20.7 / 100,000)$ and Campinas (São Paulo State; $18.6 / 100,000$ ), and inferior to those described in São Paulo $(38.2 / 100,000)$ and Porto Alegre (Rio Grande do Sul State; 70.2/100,000) 15. Among females, the prevalence is approximately three times lower than the highest rates worldwide (North America: 35.8/100,000) 2 and about half the highest incidence rates reported for other Brazilian state capitals (Porto Alegre: 21.2/100,000, Manaus: $16.8 / 100,000) 15$. Smoking is the most important risk factor for lung cancer 19 , and according to a study based on a subsample of the 2008 Brazilian National Household Sample Survey (PNAD), Acre State had the highest percentage of adult smokers $(22.1 \%)$ of all the Brazilian states 20. According to the study Surveillance of Risk and Protective Factors for Chronic Diseases (VIGITEL) 21, Rio Branco showed one of the highest prevalence rates of smoking among women (17.5\%) observed in Brazilian capital cities.

Cancer of the colon and rectum ranked as the fourth most frequent location in both sexes. The standardized incidence rate for males was $9.5 / 100,000$, well below those reported for high incidence regions (Australia: 45.7/100,000 and Western Europe: 41.2/100,000) 2. The incidence for men in Rio Branco is comparable to those reported for Campo Grande (Mato Grosso do Sul 
State) and Fortaleza (Ceará State) 15 and approximately double those described for other capitals in the North Region, such as Manaus and Belém ${ }^{15}$. Among females, the incidence rate was also much lower than those found in regions with the highest incidence rates worldwide (Australia: 30.0/100,000 andWestern Europe: 26.3/100,000) 2 and intermediate when compared to other Brazilian capital cities 15 . The etiology of these neoplasias is related to environmental factors, especially diet (low dietary intake of fruits, vegetables, and cereals), genetic predisposition, sedentarism, and obesity 2 . According to the study VIGITEL 21, the pattern of food consumption with such features as are observed in Rio Branco was the highest among those described for Brazilian capitals. Additionally, Rio Branco had the highest prevalence of excess weight (body mass index $\geq 25 \mathrm{~kg} / \mathrm{m}^{2}$ ) in adults of all capital cities in the country (52.2\%).

Cancers of the cervix and breast had the highest incidence rates among women. The high standardized incidence rate of cervical cancer found in this study is similar to those reported for regions with the highest incidence worldwide (East Africa: 34.5/100,000) 2 and higher than those reported for other parts of Brazil, such as Salvador (Bahia State), Campinas, and Porto Alegre 15. This finding may be due to a pattern of early exposure to HPV 13, made possible through the pattern of sexual behavior documented for the Acre population, with early age at first intercourse, multiple sexual partners, high frequency of intercourse and multiparity 20 . Additionally, according to the 2009 VIGITEL study 21 , in women 25 to 59 years of age Papanicolaou test screening during the prior three years reached about $86 \%$ coverage in 2009 . This high standard screening tends to increase the detection of disease cases and thus also its recorded incidence.

The incidence rate of breast cancer was about half those described for high incidence regions worldwide, such as Eastern Europe $(89.9 / 100,000)$ and Australia $(85.5 / 100,000) 2$. From the standpoint of national comparisons, the incidence of this cancer was intermediate, being lower than those observed in capitals in the South and Southeast (Porto Alegre, Curitiba, São Paulo), but higher than those observed in the Amazon (Manaus and Belém) 15. According to the VIGITEL study 21 , in 2009 about $60 \%$ of women 50 to 69 years old in Rio Branco reported having had a mammogram in the prior 2 years. This prevalence, being lower than that observed in other Brazilian capitals $(83 \%$ in Belo Horizonte and $81 \%$ in Vitória), may contribute to the increased mortality from cancer in recent years described for Rio Branco 22.
This study analyzed data on the incidence of cancer with histopathological diagnosis available in all health institutions in the city of Rio Branco for the period June 2007 to June 2009. These included data from the Hospital Cancer Registry at the Cancer Hospital of Acre, the only tertiary care hospital dedicated to the treatment of patients diagnosed with cancer from throughout the Western Amazon, and information available at the four diagnostic pathology services (three private and one public) in the municipality.

Some limitations of the present study may be identified, such as the possible noninclusion of all diagnosed cases among residents of the Municipality of Rio Branco due to diagnoses made at care centers located in other states having been missed. However, since the inauguration of the Rio Branco Cancer Hospital in 2007, and the consequent availability of services and professionals, it is unlikely that the number of such cases is able to distort the scenario portrayed regarding the distribution of malignant neoplasias.

On the other hand, this study shows certain strengths. To start, it may be mentioned that it is the first systematic survey of the incidence of cancer to be conducted in the Western Amazon, a region in which there are no populationbased cancer registries. Additionally, its results are based in their entirety on detailed records of clinical cases of patients with histopathologic diagnoses, thus faithfully portraying the different anatomical sites of cancer.

\section{Conclusions}

Taken as a whole, the epidemiological scenario portrayed in this investigation highlights the presence of an epidemiological transition characterized by the distribution of neoplasias in the Rio Branco population, with superposition of tumor sites associated with wealth conditions (breast, prostate colon, and rectum) and those accompanying living conditions deriving from poverty (cancer of the cervix, stomach, and lungs).

The results presented in this paper are pioneering among population-based studies of cancer registries in the Western Amazon. In this sense they may have the potential to assist health authorities in setting priorities and in directing control and patient assistance actions to patients diagnosed with cancer in Rio Branco, as well as throughout the Western Amazon. 


\section{Resumo}

No Brasil, as taxas de incidência de câncer variam amplamente. A literatura sobre o tema na região da Amazônia Ocidental é escassa. Este trabalho teve como objetivo determinar a incidência atual de câncer na população de Rio Branco, Acre. Registrou-se um total de 718 casos novos no período de estudo. As localizações tumorais de maior incidência em homens foram: próstata $(75,1 / 100.000)$, estômago (23,0/100.000), pulmão (19.1/100.000), cólon-reto (9,5/100.000) e leucemias (6,9/100.000) e no sexo feminino: mama (41,5/100.000), colo uterino (41,3/100.000), pulmão (11,8/100.000), cólon-reto (11,0/100.000) e estômago (7,7/100.000). Esses indicadores revelam que Rio Branco apresenta um padrão de incidência por câncer que superpõe os padrões encontrados nas regiões desenvolvidas e em desenvolvimento. Os resultados do trabalho apontam para a importância da implementação de um registro de câncer de base populacional - atualmente inexistente em Rio Branco - como fator promotor da análise de casos incidentes da doença e monitoramento de sua evolução.

Neoplasias; Incidência; Registros de Doenças

\section{Contributors}

J. P. Nakashima participated in the study design, collection, analysis and interpretation of data, and review and approval of the manuscript. S. Koifman and R. J. Koifman participated in the study design, analysis and interpretation of data, and review and approval of the manuscript.

\section{Acknowledgments}

The authors thank the directors of pathological anatomy services at the State Hospital Foundation of Acre, Acre Anatomopathological Diagnosis (DNA), Dr. Any Laboratory - Cytopathology and Pathological Anatomy, and the Laboratory of Pathological Anatomy and Cytopathology of Acre (LAC) for their commitment and scientific professionalism in making available their data for the realization of this study. This investigation was partially supported by the CAPES through the Temporary Association established between the Federal University of Acre (Masters in Public Health) and the Sergio Arouca National School of Public Health, Oswaldo Cruz Foundation (Public Health and Environment Postgraduate Program). R. J. Koifman and S. Koifman pursue research activities supported by the FAPERJ.

\section{References}

1. Guerra MR, Gallo CVM, Mendonça GAS. Risco de câncer no Brasil: tendências e estudos epidemiológicos mais recentes. Rev Bras Cancerol 2005; 51:227-34.

2. Jemal A, Bray F, Center MM, Ferlay J, Ward E, Forman D. Global cancer statistics. CA Cancer J Clin 2011; 61:69-90.
3. Wünsch FV, Moncau JEC. Mortalidade por câncer no Brasil 1980-1995: Padrões regionais e tendências temporais. Rev Assoc Méd Bras (1992) 2002; 48:250-7.

4. Koifman S, Koifman R. Environment and cancer in Brazil: an overview from a public health perspective. Mutat Res 2003; 544:305-11. 
5. Instituto Nacional de Câncer. Câncer no Brasil dados dos registros de base populacional. Rio de Janeiro: Instituto Nacional de Câncer; 2003.

6. Instituto Nacional de Câncer. Estimativa 2010: incidência de câncer no Brasil. Rio de Janeiro: Instituto Nacional de Câncer; 2009.

7. Percy C, Fritz A, Jack A, Shanmugarathan S, Sobin L, Parkin D, et al. International classification of diseases for oncology (ICD-O). 3rd Ed. Geneva: World Health Organization; 2000.

8. Organização Mundial da Saúde. Classificação estatística internacional de doenças e problemas relacionados à saúde. 10a revisão. São Paulo: Universidade de São Paulo; 1997.

9. Doll R, Payne P, Waterhouse JAH, editors. Cancer incidence in five continents. v. I. Geneva: Union Internationale Contre le Cancer; 1966

10. Ministério da Saúde. Vigitel Brasil 2008: vigilância de fatores de risco e proteção para doenças crônicas por inquérito telefônico. Brasilia: Ministério da Saúde; 2009.

11. Lino MZ, Muniz PT, Siqueira KS. Prevalência e fatores associados ao excesso de peso em adultos: inquérito populacional em Rio Branco, Acre, Brasil 2007-2008. Cad Saúde Pública 2011; 27:797-810.

12. Galduróz JCF, Caetano R. Epidemiology of alcohol use in Brasil. Rev Bras Psiquiatr 2004; 26 Suppl 1:3-6.

13. Leal EAS, Leal O, Guimarães MH, Vitoriano MN Nascimento TL, Costa OL. Lesões precursoras do câncer de colo uterino em adolescentes e adultas jovens em Rio Branco - Acre. Rev Bras Ginecol Obstet 2003; 25:81-6.
14. Viana S, Paraná R, Moreira RC, Compri AP, Macedo V. High prevalence of hepatitis B virus and hepatitis D virus in the western Brazilian Amazon. Am J Trop Med Hyg 2005; 73:808-14.

15. Instituto Nacional de Câncer. A situação do câncer no Brasil. Rio de Janeiro: Instituto Nacional de Câncer; 2006.

16. Sun L, Caire AA, Robertson CN, George DJ, Polascik TJ, Maloney KE, et al. Men older than 70 years have higher risk prostate cancer and poorer survival in the early and late prostate specific antigen eras. J Urol 2009; 182:2242-8.

17. Jemal A, Siegel R, Ward E, Hao Y, Xu J, Thun MJ. Cancer statistics, 2009. CA Cancer J Clin 2009; 59:225-49.

18. Plummer M, Franceschi S, Muñoz N. Epidemiology of gastric cancer. IARC Sci Publ 2004; (157):311-26.

19. Thun MJ, DeLancey JO, Center MM, Jemal A, Ward EM. The global burden of cancer: priorities for prevention. Carcinogenesis 2010; 31:100-10.

20. Instituto Brasileiro de Geografia e Estatística. Pesquisa Nacional por Amostra de Domicílios 2008 tabagismo. Rio de Janeiro: Instituto Brasileiro de Geografia e Estatística; 2009.

21. Ministério da Saúde. Vigitel Brasil 2009: vigilância de fatores de risco e proteção para doenças crônicas por inquérito telefônico. Brasilia: Ministério da Saúde; 2010.

22. Nakashima JP, Koifman S, Koifman RJ. Tendência da mortalidade por neoplasias malignas selecionadas em Rio Branco, AC, Brasil, 1980-2006. Cad Saúde Pública 2011; 27:1165-74.

Submitted on 12/Apr/2011

Final version resubmitted on 04/Apr/2012 Approved on 25/Jun/2012 